\title{
Food and the low incidence of IDDM in Iceland
}

\author{
By Inga Thorsdottir and Olafur Reykdal
}

\begin{abstract}
Insulin dependent diabetes mellitus (IDDM) is one of the fastest growing diseases in developed countries. All research shedding light on how to prevent IDDM is therefore of great value. The search for scientific explanations has considered genetic and environmental factors where food, especially milk, has come to play a key role. The varying incidence of IDDM among the Nordic countries provides an opportunity to investigate food factors important in the development of dietary recommendations to prevent IDDM.

The incidence of IDDM is lower in Iceland than among the genetically related nations of Scandinavia. Recent animal research in New Zealand has pinpointed a specific protein fraction in cow's milk, A1 $\beta$-casein, as one of the possible causes of an immunological destruction of the pancreatic $\beta$-cells resulting in IDDM. Milk protein allele frequencies in Nordic cattle breeds varies, and preliminary results indicate that A1 $\beta$-casein is especially low in Icelandic milk.
\end{abstract}

\section{Introduction}

The incidence of insulin dependent diabetes mellitus (IDDM) is increasing in many countries of the world (1). Finding ways to prevent the progression of the disease is therefore in the interest of the general population and public health as well as the authorities.

IDDM is a multifactorial disease believed to strike genetically susceptible individuals. Genes in the human leukocyte antigen (HLA) region either predispose or protect against the disease (2). Genetic susceptibility, however, is not the determining reason for the progression of IDDM as only some of the genetically predisposed people develop the disease, while the majority, do not. The genes make it possible for the environment to cause IDDM. Environmental factors initiate immune processes that destroy the insulin-producing $\beta$-cells of the islets of Langerhans in the pancreas.

\section{Importance of \\ environmental factors}

The increasing incidence of IDDM in a given population suggests the importance of the environment for the etiology of the disease, and so do studies on transmigratory populations. A population of Asian families moving from Pakistan, where the incidence of IDDM is extremely low, to the United Kingdom, where the incidence is much higher, takes about one generation to match the IDDM incidence of the indigenous population (3).

Robert Elliott found a high increase in IDDM incidence in a population that had moved from West Samoa to New Zealand (4). Two years later, Leslie and Elliott used this finding as well as the results from studies on identical twins and other studies to support their theory about the importance of environmental events in early childhood for the etiology of IDDM (5).

\section{Milk and IDDM}

In 1984 Borch-Johnsen et al. published data from Norway, Sweden and Denmark showing that insufficient breast-feeding might lead to IDDM in genetically susceptible individuals (6). The study was based on the theory that environmental agents trigger immunological reactions that damage $\beta$-cells, and insufficient breast-feeding allows an earlier exposure to such damaging agents. The results were confirmed by Mayer et al. in Colorado, while studies from Italy and New York did not show a relationship between insufficient breast-feeding and IDDM $(7,8,9)$.

The first food introduced in the weaning period in a majority of countries in the world is cow's milk or a cow's-milk-based formulas for infants. Cow's milk has therefore been suspected to be diabetogenic. Finnish researchers found protective effects from a long duration of breast-feeding and a late introduction of dairy products that decreased the risk of IDDM (10). Similar results were seen by Kostraba et al. in USA (11). The studies showed an increased risk of IDDM among individuals breastfed for a period shorter than 3-5 months. A very recent study from Sao Paulo has also showed that a shorter duration of breast-feeding is a risk factor for IDDM (12).

Most of the different studies on breastfeeding and cow's milk comsumption relate the consumption during infancy or early childhood to an immunological destruction leading to the progression of IDDM. IDDM also has a peak incidence much earlier in life than other diseases, that is, at school-age, which supports the importance of preschool food. Already in 1994, American Academy of Pediatrics recommended avoidance of cow's milk and products containing cow's milk protein during the first year of life for children in families with a strong history of IDDM (13). The recommendation evoked different opinions among health professionals.

Furthermore, a connection has been found between milk consumption per capita and the incidence of IDDM.

Dahl-Jørgensen et al. found a strong relationship between total cow's milk consumption in twelve countries and the incidence of IDDM, $r=0.96$ (14). Similar results were found for nine regions in Italy, $r=0.84(15)$.

Inga Thorsdottir*, Associate Professor ${ }^{1}$, Olafur Reykdal, M.S.,Food scientist ${ }^{2}$. * Correspondence. ${ }^{1}$ Unit for Nutrition Research, National University Hospital and Department of Food Science, University of Iceland, IS-101 Reykavik, Iceland. ${ }^{2}$ Department of Food Science, Agricultural Research Institute, IS-112 Reykjavík, Iceland.
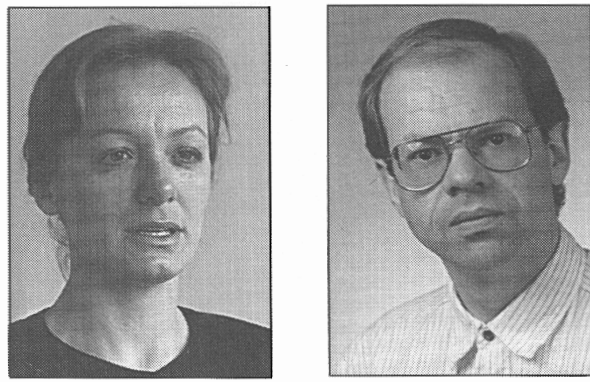
Table 1. Incidence of IDDM (age 0-14), total milk and dairy product consumption. Per capita/year in the Nordic countries.

\begin{tabular}{lcccc}
\hline & $\begin{array}{c}\text { Incidence } \\
\text { per } 100,000\end{array}$ & $\begin{array}{c}\text { Liquid milk } \\
\mathrm{kg} / \text { per capita }\end{array}$ & $\begin{array}{c}\text { Milk/milk products } \\
\mathrm{kg} / \text { per capita }\end{array}$ & Ref \\
\hline Iceland & 10 & 180 & 244 & $(17)$ \\
Denmark & 22 & 115 & 168 & $(19)$ \\
Norway & 23 & 147 & 178 & $(20)$ \\
Sweden & 24 & 126 & 189 & $(21)$ \\
Finland & 35 & 170 & 244 & $(22)$
\end{tabular}

\section{Milk consumption - incidence of IDDM}

The study of Dahl-Jørgensen et al. included, among other countries, Denmark, Norway, Sweden and Finland. All these countries have a high consumption of milk and a high incidence of IDDM, Finland being the highest in both. The milk consumption in Iceland is the highest known world-wide, the total consumption being $180 \mathrm{~kg} /$ person/year of liquid milk, and the total consumption of dairy products is similar to that in Finland, $244 \mathrm{~kg} /$ person/ year (16). However, as recently presented in this journal, the incidence of IDDM is lower in Iceland than in many other countries and is fairly constant, compared with the increasing incidence world-wide (1, 17,18). Results from epidemiological studies on IDDM have shown a high and increasing incidence in Denmark, Norway, Sweden and Finland $(19,20,21,22)$. The consumption in the five Nordic countries of fluid milk and dairy products and the incidence of IDDM are shown in Table 1.

The hypothesis of a connection between high cow's milk consumption and IDDM obviously contradicts the Icelandic situation of high milk consumption and a low incidence of IDDM. The lower incidence of IDDM in Iceland cannot be explained with a difference in breast-feeding frequency or duration since the frequency of breast-feeding is similar and high in all the Nordic countries (23). As discussed earlier, the lower incidence of IDDM in Iceland, compared with the Scandinavian countries, cannot be explained by heritage, climate or infectious diseases because of the similarities between the countries $(1,17,18)$.

\section{Proteins in cow's milk: bovine albumin}

Finnish scientists have studied components of cow's milk that are potentially diabetogenic. These studies were thoroughly discussed in this journal last year (24).
Building on studies of a bovine albumin peptide acting as a trigger of IDDM in rodents, Karjalainen et al. found that all newly diagnosed diabetic children had elevated serum concentrations of $\mathrm{IgG}$ anti-bovine serum albumin antibodies, compared with healthy children (25). IgA antibodies were also elevated but not those of IgM. After diagnosis, the concentrations declined and had reached normal levels in most patients within 1-2 years. The bulk of IgG antibodies were specific to the bovine serum albumin peptide, and it was concluded that the antibodies could play a role in the development of islet dysfunction leading to diabetes (25). A year later, Atkinson et al. argued that the reaction to bovine albumin was also found in patients with other autoimmune diseases. They did not find a similar elevation of antibodies in all newly diagnosed diabetic patients (26). They concluded that anti-bovine serum albumin antibodies may be connected with a defect in immunologic tolerance rather than immunity specific to $\beta$-cells. Atkinson et al. did not support a role for the antigen in the pathogenesis of the diabetic disorder (26). Other studies have been performed, but the results are not in agreement. It seems clear that bovine serum albumin cannot be regarded as the only explanation (27). Elevated levels of antibodies to $\beta$ lactoglobulin have also been seen in IDDM-patients (28).

Norris et al. have raised doubts about the importance of early exposure to cow's milk for the etiology of diabetes as they did not find any connection between $\beta$ cell-autoimmunity and infant dietary exposure to cow's milk (29).

\section{Proteins in cow's milk: A1 $\beta$-casein}

Cavallo et al. found significantly higher levels of antibodies to cow's milk $\beta$-casein in children newly diagnosed with IDDM than in healthy controls or individuals with autoimmune thyroid diesease. They concluded that early consumption of cow's milk may generate a specific immune response to $\beta$-casein that could lead to IDDM (30). Research on non-obese-diabetes (NOD) mice showed that a diet without casein prevented IDDM (31). Recent research in New Zealand has lead to the hypothesis that the protein fraction of A1 $\beta$-casein in cow's milk may be the triggering factor. Studies on NOD mice showed a destruction of insulin-producing $\beta$-cells caused by A1 $\beta$-casein. Varying amounts of A1 protein were given, and the more $\mathrm{A} 1$ protein in the diet, the higher the risk of IDDM (personal communication, D. Paul Harris and Jeremy P. Hill, New Zealand Dairy Research Institute). The difference between $\mathrm{A} 1$ and $\mathrm{A} 2 \beta$-casein lies in only one amino acid, but during digestion $\mathrm{A} 1$ is converted to $\beta$-casomorphin that can disturb the immune reaction (32). Preliminary results from a multinational study on IDDM children showed increased levels of antibodies against A1 and A2 among the diabetic children, compared with controls (33). How the A1 $\beta$-casein affects the immune system, which may initiate the development of IDDM, is far from clear, but preliminary results emphasise the importance of further research.

\section{Low A1 $\beta$-casein in Icelandic cow's milk}

Recent studies on milk protein allele frequencies in Nordic cattle breeds show that Icelandic cattle have a low frequency of A1 $\beta$-casein, about half that in bigger Nordic cattle breeds (personal communication, Stefan Adalsteinsson, the Nordic Gene Bank for Farm Animals, Ås, Norway). Preliminary results from analyses of A1 $\beta$-casein in milk have also indicated such a difference. This merits a thorough investigation. The first step is to confirm that the proportion of $\beta$-casein $A 1$ is lower in Icelandic milk than in milk from the largest areas in Scandinavia by using the same method of analysis on all milk samples. If a lower proportion is confirmed, further studies are warranted.

\section{Other food factors}

In addition to milk, many other dietary factors have been related to the etiology of IDDM. A retrospective study found a higher consumption of protein, carbohydrate and nitrosamine compounds among IDDM patients, in the year prior to diagnosis, than among controls (34). Nitrosamines have been shown to be diabetogenic in the male offspring of mice. This finding was put forward as a possible explanation of the higher frequency of IDDM among boys born in October in 
Iceland, where smoked lamb is a traditional food item during Christmas (35). A Finnish study on the intake of nitrate and nitrite found that diabetic children and their mothers received significantly more nitrite from their diet than non-diabetic controls (36). The same researchers found an increased risk of IDDM developing in children who consumed coffee or tea regularly (37). Wheat gluten and soy have been shown to be diabetogenic in NOD mice (38) while nicotinamide has been shown to prevent or delay the onset of IDDM (31).

High weight gain early in life, which must be considered to be strongly related to food intake, has been associated with an increased risk of IDDM later in life (39). One theory is that these results may be

\section{References}

1. Karvonen M, Tuomilehto J, Libman I, Laporte R. WHO DIAMOND Project Group: A review of the recent epidemiological data on the worldwide incidence of Type 1 (insulin-dependent) diabetes mellitus. Diabetologia 1993; 36:883-93.

2. Todd JA, Bell JI, McDevitt HO: HLA DQ Bgene contributes to susceptibility and resistance to insulin-dependent diabetes mellitus. Nature 1987;329:599-604.

3. Bodansky HJ, Staines A, Stephenson C, Haigh D, Cartwright R: Evidence for an environmental effect in the aetiology of insulin dependent diabetes in a transmigratory population. $\mathrm{Br}$ Med J 1992;304:1020-2.

4. Elliott RB: Epidemiology of diabetes in Polynesia and New Zealand. Pediatr Adolesc Endocrinol 1992;21:66-71.

5. Leslie RDG, Elliott RB: Early environmental events as a cause of IDDM. Diabetes 1994; 43:843-50.

6. Borch-Johnsen K, Joner G, Mandrup-Poulsen T, Christy M, Zachau-Christiansen B, Kastrup K, Nerup J: Relation between breast-feeding and incidence rates of insulin-dependent diabetes mellitus. Lancet 1984;2:1083-6.

7. Mayer EJ, Hamman RF, Gay EC, Lezotte DC, Savitz DA, Klingensmith GJ: Reduced risk of IDDM among breast-fed children. Diabetes 1988;37:1625-32.

8. Nigro G: Breast-feeding and insulin-dependent diabetes mellitus. Letter. Lancet 1985;1:467.

9. Fort P, Lanes R, Dahlem S, Recker B, WeymanDaum M, Pugliese M, Lifshitz F: Breast feeding and insulin-dependent diabetes mellitus in children. J Am Coll Nutr 1986;5:439-41.

10. Virtanen SM, Räsänen L, Aro A, Lindström J, Sippola H, Lounamaa R, Toivanen L, Tuomilehto J, A kerblom HK: Infant feeding in finnish children $<7 \mathrm{yr}$ of age with newly diagnosed IDDM. Diabetes Care 1991;14:415-7.

11. Kostraba JN, Cruickshanks KJ, Lawler-Heavner J, Jobim LF, Rewers MJ, Gay EC, Chase HP, Klingensmith G, Hamman RF: Early exposure to cow's milk and solid foods in infancy, genetic predisposition, and risk of IDDM. Diabetes 1993;42:288-95.

12. Gimeno SGA, Desouza JMP: IDDM and milk consumption. A case-control study in Sao Paulo, Brazil. Diabetes Care 1997;20:1256-60.

13. American Academy of Pediatrics: Infant feeding practices and their possible relationship to the etiology of diabetes mellitus. Work Group on Cow's Milk Protein and Diabetes Mellitus. Pediatrics 1994;94:752-4.

14. Fava D, Leslie DG, Pozzilli P: Relationship explained by an early introduction of a food, such as cow's milk, in the infant's diet and a short duration of exclusive breastfeeding. Infants breastfed exclusively gain less weight than those getting other food items early.

\section{The prevention of IDDM}

The promising research on environmental factors triggering the onset of IDDM may shed light on fundamental strategy for the primary prevention of IDDM. In the future, we may have to decide whether primary prevention should focus on a defined risk group or on a whole population. It has been put forward that primary prevention of IDDM cannot be effected by predicting the risk among first-degree relatives of IDDM as $90 \%$ of the future cases will have no close relative with IDDM (40). Any prediction of a risk group would have to be from the whole population.

This makes stringent demands on the test in terms of accuracy, low cost and convenience. The tests now available, though promising, are far short of fulfilling these criteria (11).

It seems reasonable to believe that in the future, we will have a list of diabetogenic environmental factors, where food factors will probably be predominant. The items on such a list will most likely vary in how well their relation to IDDM is documented, and how strong the relationship is in various parts of the world. However, if the diabetogenic environmental factors can be easily avoided, it might be a priority to do so for the whole population. between dairy product consumption and incidence of IDDM in childhood in Italy. Diabetes Care 1994:17:1488-90.

15. Dahl-Jørgensen K, Joner G, Hanssen KF: Relationship between cow's'milk consumption and incidence of IDDM in childhood. Diabetes Care 1991;14:1081-3.

16. Consumption statistics for milk and milk products 1993. Bulletin of the International Dairy Federation 1995:301,

17. Helgason $T$, Danielsen $R$, Thorsson AV Incidence and prevalence of Type 1 (insulindependent) diabetes mellitus in Icelandic children1979-1989. Diabetologia 1992;35:880-3.

18. Thorsdottir I: Low prevalence of diabetes mellitus in Iceland. Possible relations to food? A nutrition and diabetes study group project. Scand J Nutr/Näringsforskning 1997;3:146.

19. Geen A, Gale EAM, Patterson CC for the EURODIAB ACE study group: Incidence of childhood-onset insulin-dependent diabetes mellitus: the EURODIAB ACE study. Lancet 1992;339:905-9.

20. Joner G, Søvik O: Increasing incidence of diabetes mellitus in Norwegian children 0 - 14 years of age 1973-1982. Diabetologia 1989; 32:79-83.

21. Nyström L, Dahlquist G, Rewers M, Wall S: The Swedish childhood diabetes study. An analysis of the temporal variation in diabetes incidence 1978 - 1987. Int J Epidemiol 1990;19:141-6.

22. Tuomilehto J, Karvonen M, Padsiga Z, Tuomilehto-Wolf E, Kohtamaki K: Epidemiology of insulin-dependent diabetes mellitus around the Baltic Sea. The DIABALT Study Group. Hormone and Metabolic Research 1996:28:340-3.

23. Nordiska Näringsrekommendationer 1996. Nord 1996:28. Utg. Nordiska ministerrådet Köpenhamn, 1996.

24: Åkerblom, HK, Savilahti E, Vaarala O:Cow's milk protein and insulin-dependent diabetes mellitus. Scand J Nutr/Näringsforskning 1996; 40:98-103.

25. Karjalainen J, Martin JM, Knip M, Ilonen J, Robinson BH, Savilahti E, Ákerblom HK, Dosch HM: A bovine albumin peptide as a possible trigger of insulin-dependent diabetes mellitus. New Eng J Med 1992;327:302-7.

26. Atkinson MA, Bowman MA, Kao KJ Campbell L, Dush PJ, Shah SC, Simell O, Maclaren NK: Lack of immune responsiveness to bovine serum albumin in insulin-dependent diabetes. New Eng J Med 1993; 329:1853-8.

27. Hammond-McKibben D, Dosch H-M: Cow's milk, bovine serum albumin, and IDDM: Can we settle the controversies? Diabetes Care 1997;20:897-901.
28. Vaarala U, Klementi P, Savilahti E, Reijonen H, Ilonen J, Akerblom HK: Cellular immune response to cow's milk $\beta$-lactoglobulin in patients with newly diagnosed IDDM. Diabetes 1996;45:178-82.

29. Norris JM, Beaty B, Klingensmith G, et al: Lack of association between early exposure to cow's milk protein and $\beta$-cell autoimmunity; Diabetes Autoimmunity Study in the Young (DAISY). JAMA 1996;276:609-14

30. Cavallo MG, Fava D, Monetini L, Barone F, Pozzilli P: Cell-mediated immune response to beta casein in recent-onset insulin-dependent diabetes: implications for disease pathogenesis. Lancet 1996;348:926-8.

31. Reddy S, Bibby NJ, Wu D, Swinney C, Barrow G, Elliott RB: A combined casein-free- nicotinamide diet prevents diabetes in the NOD mouse with minimum insulitis. Diabetes Research and Clinical Practice 1995;29:83-92.

32. Elitsur Y, Luk GD: Beta-casomorphin (BCM) and human colonic lamina propria lymphocyte proliferation. Clin Exp Immunol 1991;85:493-7.

33. Elliott RB. Wasmuth H, Hill J, Songini M, Bottazzo GF: Diabetes and cow's milk. (Letter, comment). Lancet 1996;348:1657.

34. Dahlquist GG, Blom LG, Persson L- $\AA$ Sandström AIM, Wall SGI: Dietary factors and the risk of developing insulin dependent diabetes in childhood. BMJ 1990;300:1302-6.

35. Helgason T, Ewen SWB, Ross IS, Stowers JM Diabetes produced in mice by smoked/cured mutton. Lancet 1982;2:1017-24.

36. Virtanen SM, Jaakkola L, Rasanen L, Ylonen K, Aro A, Lounanmaa R, Åkerblom HK, Tuomilehto J: Nitrate and nitrite intake and the risk for type 1 diabetes in Finnish children. Childhood Diabetes in Finland Study Group. Diabetic Medicine 1994:11:656-62.

37. Virtanen SM, Räsänen L, Aro A, Ylonen K Lounamaa R, Åkerblom HK, Tuomilehto J: Is children's or parents' coffee or tea consumption associated with the risk for type 1 diabetes mellitus in children? Childhood Diabetes in Finland Study Group. Eur J Clin Nutr 1994; 48:279-85

38. Scott FW: Food, diabetes and immunology. In: Forse RA, Bell JS, Blackburn GL, Kabbash LG, eds. Diet, Nutrition and Immunity: Boca Raton, FL: CRC Press; 1994:73-95.

39. Johansson C, Samuelsson U, Ludvigsson J: A high weight gain early in life is associated with an increased risk of Type 1 (insulin-dependent) diabetes mellitus. Diabetologia 1994;37:91-4.

40. Bingley PJ, Bonifacio E, Gale EAM: Can we really predict IDDM? Diabetes 1993:42:213-9. 